\title{
Compost quality and its function as a soil conditioner of recultivation layers - a critical review**
}

\author{
Steffen Beck-Broichsitter*, Heiner Fleige, and Rainer Horn \\ Institute of Plant Nutrition and Soil Science, Christian Albrechts University Kiel, Germany
}

Received September 25, 2017; accepted December 7, 2017

\begin{abstract}
During a period of 4 years, soil chemical and physical properties of the temporary capping system in Rastorf (Northern Germany) were estimated, whereby compost was partly used as soil improver in the upper recultivation layer. The air capacity and the available water capacity of soil samples were first determined in 2013 (without compost), and then in 2015 (with compost) under laboratory conditions. Herein, the addition of compost had a positive effect on: the air capacity up to $13.4 \mathrm{~cm}^{3}$ $\mathrm{cm}^{-3}$; and the available water capacity up to $20.1 \mathrm{~cm}^{3} \mathrm{~cm}^{-3}$ in 2015 , in the recultivation layer $(0-20 \mathrm{~cm})$. However, taking into account the in situ results of the tensiometer and frequency domain reflectometry measurements, the addition of compost had a negative effect. The soil-compost mixture led to restricted remoistening even after a normal summer drying period in autumn and induced more negative matric potentials in the recultivation layer. In summary, the soil-improving effect of the compost addition, in conjunction with an increased water storage capacity, is undeniable and was demonstrated in a combined field and laboratory study. Therefore, intensive hydrophobicity can inhibit the homogeneous remoistening of the soil, resulting in a decreased hydraulic effectiveness of the sealing system.

Keywords: Rastorf landfill, temporary capping system, compost quality, plant available water capacity, air capacity, hydrophobicity
\end{abstract}

\section{INTRODUCTION}

Municipal solid waste landfills still represent the major option for waste disposal. In total, 340 million $\mathrm{Mg}$ of municipal solid waste per year are directly disposed worldwide (Hoornweg and Bhada-Tata, 2012). Prior to the final complete sealing of waste deposits, a transition period is required in order to support the decomposition process while neither the atmosphere nor the groundwater is afflicted by

*Corresponding author e-mail: s.beck-broichsitter@soils.uni-kiel.de **This research was supported by the Innovation Foundation Schleswig-Holstein and the ZMD Rastorf GmbH, Germany, 2008-2016. contaminants. Thus, the construction of partially permeable layers is necessary to stimulate the biochemical decomposition processes in the waste body by controlled moisture with regard to potential settlements (Beck-Broichsitter et al., 2017; Rowe, 2011; Stępniewski et al., 2011).

The design and the determination of the layer thickness of the temporary landfill capping system in Rastorf (Northwest Germany) are adapted to maintain both the water balance and physical properties of the utilized natural origin boulder marl (Widomski et al., 2015). It is the subtarget of the temporary landfill capping system to minimize the drainage of precipitation water towards the compacted surface sealing layer and into the underlying waste body by maximizing the evapotranspiration rate from the soil surface and the locally appropriate vegetation by improved plant growth due to compost addition (Laner et al., 2012; Stepniewski et al., 2011). In the European Union, aerobically composted organic materials are either used as organic fertilizers in agriculture or provide the structural and vegetative stability of recultivation areas (e.g. landfill capping systems or post-mining landscapes). The objective of compost addition after the landfill construction phase is to ensure a quick plant and root growth, in order to improve the soil structure, the water stability of the soil aggregates (Scheffer/Schachtschabel, 2016) and the water storage capacity of the recultivation layer which, in turn, helps to prevent drought stress and potential soil erosion processes. However, interactions between soil matrix and compost with various amounts of fatty acids, especially contained in anaerobically produced substances, can modify soil wettability (Bayer and Schaumann, 2007) and contribute to soil

(C) 2018 Institute of Agrophysics, Polish Academy of Sciences 
hydrophobicity (Hallett and Young, 1999). Furthermore, the potential influence of compost addition on delaying the shrinkage crack formation at a given matric potential (which is defined at the transition from the structural shrinkage to the proportional shrinkage range, see section 2.2) has to be linked with the potential of surface hydrophobization which may have a negative impact on the functionality of the capping system.

We hypothesized that the addition of compost implies improved plant available water storage capacity related to an improved plant growth of the recultivation layer of the temporary capping system in Rastorf. However, the final decision depends on the matric potential dependent formation of hydrophobized surfaces which counteracts the positive effects of an improved water storage.

Therefore, the objectives of this field and laboratory study were:

- to determine the effects of compost on soil characteristics with special focus on air capacity and plant available water storage capacity, and

- to investigate the effect of the soil-compost mixture on the hydraulic effectiveness of the sealing layer under in situ conditions in 2012 and 2015.

\section{MATERIALS AND METHODS}

The Rastorf landfill (lat. $54^{\circ} 16^{\circ} \mathrm{N}$, long. $10^{\circ} 19^{\circ} \mathrm{E}$ ) in Schleswig-Holstein (Northwest Germany) is located approximately $25 \mathrm{~km}$ east of Kiel. During the period until May 31, 2005, about 2.0 million tons of municipal domestic wastes were deposited in the landfill. In the cross-section, it incorporates a $100 \mathrm{~cm}$-thick mineral temporary capping system with a partially permeable recultivation layer $(70 \mathrm{~cm})$ and a low permeable $30-\mathrm{cm}$-thick mineral sealing layer which functions as a water and root growth barrier to prevent leachate from leaving the landfill and entering the groundwater. The capping system also includes a levelling layer above the waste body and a groundwater barrier in terms of drainage, as well as a bottom layer (Fig. 1).

In July 2013, compost produced by the local composting facility (Rastorf, Northern Germany), made out of trees and shrub chippings and debris, was added by a milling machine to the upper $20 \mathrm{~cm}$ of the recultivation layer.

The maritime climate in Rastorf (Northern Germany) affects the water balance of the landfill capping system. It generates average precipitation rates of 655 to $767 \mathrm{~mm}$, and average annual temperatures of 8.9 to $10.1^{\circ} \mathrm{C}(2012$ to 2015 data). The landfill is covered with a pasture with a dominant share of cocksfoot (Dactylis glomerata), red fescue (Festuca rubra) and meadow grass (Poa pratensis). A biannual mowing is carried out.

In 2013 (without compost) and in 2015 (with compost), more than 160 undisturbed soil cores (diameter: $5.5 \mathrm{~cm}$, height: $4 \mathrm{~cm}$ ) were collected at a slightly sloped culmination area in the north-east part of the landfill $\left(54^{\circ} 28^{\circ} \mathrm{N}\right.$,

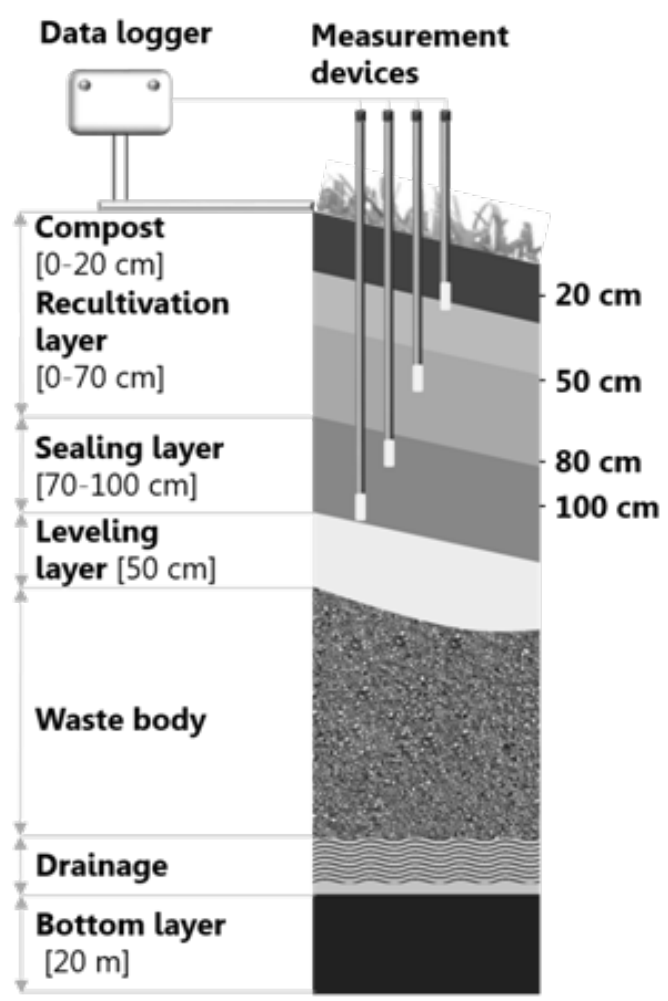

Fig. 1. Cross-section through the landfill after compost addition showing data logger and measurement device placements.

$10^{\circ} 32^{\circ} \mathrm{E}$ ) in depths of $5,20,50$ and $80 \mathrm{~cm}$. The dry bulk density was determined by the core method (Blake and Hartge, 1986) and the saturated hydraulic conductivity (Ks) was measured under in-stationary conditions (10 replicates per depth) according to Hartge (1966). Disturbed soil cores were used to measure particle density (the pycnometer method); the organic carbon content was determined by combustion and coulometric carbon dioxide $\left(\mathrm{CO}_{2}\right)$ measurement; soil texture was analysed by the combined sieve $(>63 \mu \mathrm{m})$ and pipette method (Scheffer/Schachtschabel, 2016). The soil pH content required a $0.01 \mathrm{M} \mathrm{CaCl}_{2}$ solution (1:2 soil/suspension) prepared according to Blakemore et al. (1987).

The water retention parameters were measured immediately from undisturbed soil cores (10 replicates per depth) by a combined pressure plate (saturated, $-30,-60,-150$, $-300,-500 \mathrm{hPa}$ ) and a $15000 \mathrm{hPa}$ ceramic vacuum outflow method, as well as after being oven-dried for 16 hours at $105{ }^{\circ} \mathrm{C}$, respectively (Scheffer/Schachtschabel, 2016). Simultaneously, the soil volume change at the different drying stages was estimated with the laser triangulation method. The texture classification and the $\rho_{t}$ values are based on FAO (2006).

The chemical properties of the compost used in this study are provided in Table 1 . The dry substance content is $52 \%$, with $\mathrm{pH}$ value of 8.1 and an organic matter content of $32 \%$. The content of total nitrogen, phosphorus pentoxide, 
potassium oxide, magnesium oxide and calcium oxide of the dry substance amounts to $1.2,0.3,0.6,0.4$, and $2.2 \%$, respectively.

The generated shrinkage curve can be divided into four characteristic zones, which indicate different structural rigidities from wet to dry conditions. The structural shrinkage zone includes a phase of dehydration during which air entries and the large, water-filled pores induce a negligible volume change, while the ongoing dehydration impacts on the proportional shrinkage behaviour where the menisci forces lead to a volume loss being proportional to the water loss (Gebhardt et al., 2010; Scheffer/Schachtschabel, 2016). At the point where the additional volume loss becomes lower than the water loss, the residual shrinkage phase is reached until the soil volume draws forward zero (zero shrinkage).

Therefore, we define the critical matric potential at the transition from the structural to the proportional shrinkage phase as ranging between -300 and $-500 \mathrm{hPa}$ for the boulder marl. This indicates the rigidity limits of the utilized sealing materials in accordance with the previous studies of BeckBroichsitter et al. (2016).

In the period between 2012 and 2015, tensiometers and FDR (frequency domain reflectometry) sensors, based on the dielectric permittivity of porous materials, continuously recorded the matric potential and the volumetric water content in 20,50,80 and $100 \mathrm{~cm}$ depths with three replications per depth, on an hourly basis, in order to quantify soil water dynamics (Fig. 1). The matric potential and water content were recorded using tensiometers (Tensio 151) and Theta Probe ML2x soil moisture sensors (Umwelt-Geräte-Technik GmbH, Müncheberg, Germany). The soil-specific calibration of the FDR probes was carried out by a second-degree polynomical function based on Saito et al. (2013). The measuring probes of the sensors were separately connected to a standard data logger DL 200 (Umwelt-Geräte-Technik GmbH, Müncheberg, Germany). Additionally, a weather station located close to the landfill recorded the actual meteorological data (including precipitation, air temperature, wind speed, wind direction, air pressure, relative humidity and solar radiation). The actual evapotranspiration calculations are based on the potential evapotranspiration for grassland vegetation according to the Penman-Monteith formula (Allen et al., 1998) and a relation of actual to reference evapotranspiration typical for Schleswig-Holstein (Widomski et al., 2015).

\section{RESULTS}

The sandy loam textured boulder marl was found to have an alkaline character $(\mathrm{pH}$ 7.4-7.7) and an increased organic carbon content (OC), ranging from 1.2 to $4.6 \mathrm{~g} \mathrm{~kg}^{-1}$ (Table 2), while the dry bulk density $\left(\rho_{t}\right)$ was found to decrease from 1.42 to $1.13 \mathrm{~g} \mathrm{~cm}^{-3}$ due to the compost addition in the upper part of the recultivation layer (Table 3 ). The

Table 1. Average dry substance content (DS), $\mathrm{pH}$ value, nutrient and organic matter content (OM) of the compost (comprising tree and shrub detritus) (Rastorf, Northern Germany)

\begin{tabular}{ccccccccc}
\hline \multirow{2}{*}{$\begin{array}{c}\text { Depth } \\
(\mathrm{cm})\end{array}$} & $\mathrm{DS}$ & $\mathrm{pH}$ & $\mathrm{OM}$ & $\mathrm{Nt}$ & $\mathrm{P}_{2} \mathrm{O}_{5}$ & $\mathrm{~K}_{2} \mathrm{O}$ & $\mathrm{MgO}$ & $\mathrm{CaO}$ \\
\cline { 2 - 9 } & $(\%)$ & $\left(\mathrm{CaCl}_{2}\right)$ & & & $(\% \mathrm{DS})$ & & & \\
\hline Compost & 52 & 8.1 & 32 & 1.2 & 0.3 & 0.6 & 0.4 & 2.2 \\
\hline
\end{tabular}

Tab le 2. Basic soil characteristics of the landfill capping system with compost $(0-20 \mathrm{~cm})$ and without compost $(0-5 \mathrm{~cm}), \mathrm{n}=4 \mathrm{repeated}$ measurements for organic carbon, $\mathrm{pH}$ value and texture

\begin{tabular}{|c|c|c|c|c|c|}
\hline \multirow{2}{*}{$\begin{array}{c}\text { Depth } \\
(\mathrm{cm})\end{array}$} & \multirow{2}{*}{$\begin{array}{c}\mathrm{OC} \\
\left(\mathrm{g} \mathrm{kg}^{-1}\right)\end{array}$} & \multirow{2}{*}{$\begin{array}{c}\mathrm{pH} \\
\left(\mathrm{CaCl}_{2}\right)\end{array}$} & Sand & Silt & Clay \\
\hline & & & \multicolumn{3}{|c|}{$\left(\mathrm{g} \mathrm{kg}^{-1}\right)$} \\
\hline $0-20^{*}$ & 4.6 & 7.6 & $78 \pm 2$ & $13 \pm 1$ & $9 \pm 1$ \\
\hline $20-40^{*}$ & 0.8 & 7.6 & $78 \pm 2$ & $12 \pm 2$ & $10 \pm 2$ \\
\hline $40-70^{*}$ & 0.4 & 7.7 & $67 \pm 3$ & $22 \pm 1$ & $11 \pm 1$ \\
\hline $70-100^{* *}$ & 0.4 & 7.7 & $73 \pm 2$ & $19 \pm 1$ & $8 \pm 2$ \\
\hline $0-5^{*}$ & 1.2 & 7.4 & $80 \pm 1$ & $13 \pm 2$ & $7 \pm 2$ \\
\hline $5-40^{*}$ & 0.9 & 7.6 & $80 \pm 3$ & $12 \pm 1$ & $8 \pm 1$ \\
\hline $40-70^{*}$ & 0.5 & 7.6 & $68 \pm 2$ & $21 \pm 2$ & $11 \pm 1$ \\
\hline $70-100 * *$ & 0.2 & 7.7 & $72 \pm 2$ & $19 \pm 2$ & $8 \pm 2$ \\
\hline
\end{tabular}

*Recultivation and $* *$ sealing layers. The symbol \pm corresponds to the standard deviation. 
Table 3. Soil physical characteristics of the landfill capping system with compost $(0-20 \mathrm{~cm})$ and without compost $(0-5 \mathrm{~cm}), \mathrm{n}=20$ undisturbed soil cores per depth and variation

\begin{tabular}{cccccc}
\hline \multirow{2}{*}{$\begin{array}{c}\text { Depth } \\
(\mathrm{cm})\end{array}$} & TP & AC & AWC & $\begin{array}{c}\rho_{t} \\
\left(\mathrm{~g} \mathrm{~cm}^{-3}\right)\end{array}$ & $\begin{array}{c}\text { Ks } \\
\left(\mathrm{m} \mathrm{s}^{-1}\right)\end{array}$ \\
\cline { 2 - 3 }$\left(\mathrm{cm}^{3} \mathrm{~cm}^{-3}\right)$ & $13.4 \pm 0.7$ & $20.1 \pm 1.6$ & $1.13 \pm 0.1$ & $2.2 \pm 1.2 \mathrm{e}-05$ \\
$0-20^{*}$ & $38.1 \pm 1.0$ & $6.9 \pm 0.9$ & $12.3 \pm 1.9$ & $1.79 \pm 0.1$ & $3.1 \pm 2.1 \mathrm{e}-06$ \\
$20-40^{*}$ & $30.7 \pm 1.7$ & $5.5 \pm 0.6$ & $12.1 \pm 0.5$ & $1.83 \pm 0.1$ & $6.2 \pm 2.4 \mathrm{e}-07$ \\
$40-70^{*}$ & $29.4 \pm 1.6$ & $4.8 \pm 0.8$ & $11.8 \pm 0.7$ & $1.88 \pm 0.1$ & $2.4 \pm 1.8 \mathrm{e}-07$ \\
$70-100^{* *}$ & $29.0 \pm 0.7$ & $6.4 \pm 1.2$ & $11.8 \pm 0.8$ & $1.42 \pm 0.1$ & $7.2 \pm 2.1 \mathrm{e}-06$ \\
$0-5^{*}$ & $30.2 \pm 0.5$ & $5.6 \pm 0.7$ & $10.5 \pm 1.4$ & $1.77 \pm 0.1$ & $3.4 \pm 1.6 \mathrm{e}-06$ \\
$5-40^{*}$ & $29.8 \pm 1.0$ & $4.9 \pm 0.7$ & $12.5 \pm 1.4$ & $1.82 \pm 0.1$ & $7.2 \pm 3.1 \mathrm{e}-07$ \\
$40-70^{*}$ & $29.1 \pm 1.2$ & $5.4 \pm 0.3$ & $11.4 \pm 0.7$ & $1.86 \pm 0.4$ & $2.1 \pm 1.3 \mathrm{e}-07$ \\
$70-100^{* *}$ & $28.6 \pm 1.3$ & & & \\
\hline
\end{tabular}

*Recultivation and **sealing layers. The symbol \pm corresponds to the standard deviation.

bottom part, the recultivation layer (5 or rather 20-70 m) with a prismatic-platy structure, as well as the more compacted sealing layer $(70-100 \mathrm{~cm})$ with a platy structure, were characterised by a low organic carbon content $<1 \%$, $\mathrm{pH}$ values between 7.6-7.7 and intermediate to firm $\rho_{t}$ values between 1.77 and $1.88 \mathrm{~g} \mathrm{~cm}^{-3}$. The total coverage of the grassland mixture varied between 85 to $100 \%$, and the rooting depth without compost was limited to $20-25 \mathrm{~cm}$. In contrast, the maximum rooting depth increased up to $40 \mathrm{~cm}$ with the compost addition.

The Ks values increased from $7.210^{-6}$ up to $2.210^{-5}$ $\mathrm{m} \mathrm{s}^{-1}$ due to the compost addition in the upper part of the recultivation layer. Moreover, the total porosities (TP) differ between 28.6 and $30.7 \mathrm{~cm}^{3} \mathrm{~cm}^{-3}$, though higher total porosities up to $38.1 \mathrm{~cm}^{3} \mathrm{~cm}^{-3}$ were achieved after compost addition.

The air capacities (AC) of 4.9 to $6.9 \mathrm{~cm}^{3} \mathrm{~cm}^{-3}$ increased with compost addition up to $13.4 \mathrm{~cm}^{3} \mathrm{~cm}^{-3}$ in the more slightly compressed upper part of the recultivation layer $(0-20 \mathrm{~cm})$. Regarding water storage capacities, a similar effect induced by the compost addition was indicated by a higher plant available water capacity (AWC) of $20.1 \mathrm{~cm}^{3}$ $\mathrm{cm}^{-3}$, compared to $11.8 \mathrm{~cm}^{3} \mathrm{~cm}^{-3}$ without compost.

The monitoring period between 2012 and 2015 was characterised by the occurrence of the drier years 2012 and 2013, with annual precipitation rates of 655 and $699 \mathrm{~mm}$ year $^{-1}$, and the more humid years 2014 and 2015, with annual precipitation rates of 753 and $767 \mathrm{~mm}$. Furthermore, the evapotranspiration rates increased due to the ongoing annual vegetation growth, from $<0.2 \mathrm{~mm}_{\text {day }}{ }^{-1}$ during the winter months to up to $5.5 \mathrm{~mm}^{\text {day }}{ }^{-1}$ during the vegetation period (Fig. 2).
The seasonal dynamics of precipitation and evapotranspiration brought about variations in soil water storage, including swelling and shrinkage periods, especially in the upper part of the recultivation layer. This was less pronounced in the sealing layer.

During the growing season, i.e. between April and October 2012, the recultivation layer was characterised by demonstrating matric potentials down to $-425 \mathrm{hPa}$, with a water content of 16.6-22.8 $\mathrm{cm}^{3} \mathrm{~cm}^{-3}$ and a degree of saturation between 47 and $72 \%$. Moreover, the dense sealing layer below $70 \mathrm{~cm}$ never dried out to matric potential values smaller than $-60 \mathrm{hPa}$, which is equivalent to a water content $\geq 27.8 \mathrm{~cm}^{3} \mathrm{~cm}^{-3}$. Therefore, the static conditions of the capping system were maintained by the sealing layer, especially during the humid winter months wherein it displayed nearly saturated conditions.

In contrast, the addition of compost in July 2013 led to more negative matric potentials in the recultivation layer down to $-900 \mathrm{hPa}$ (where the measurement range becomes limited) with a water content of 13.1-17.5 $\mathrm{cm}^{3} \mathrm{~cm}^{-3}$ and a degree of saturation between 34 and $46 \%$ during the drier summer month.

In this case, a restricted remoistening in the summer and autumn seasons, with more negative matric potentials in the recultivation layer, was detected and can be related to the hydrophilic and hydrophobic properties of the organic particles, leading to hydrophobicity due to the compost addition. These interactions also caused a more intense root water uptake followed by more intense shrinkage of the topsoil material and the formation of a granular or rather prismatic-platy structure. However, this drying out was limited to the amended topsoil layers, where the decreasing functionality (i.e. shrinkage cracks) due to critical matric potentials of -300 to $-500 \mathrm{hPa}$ was detected, while in the 

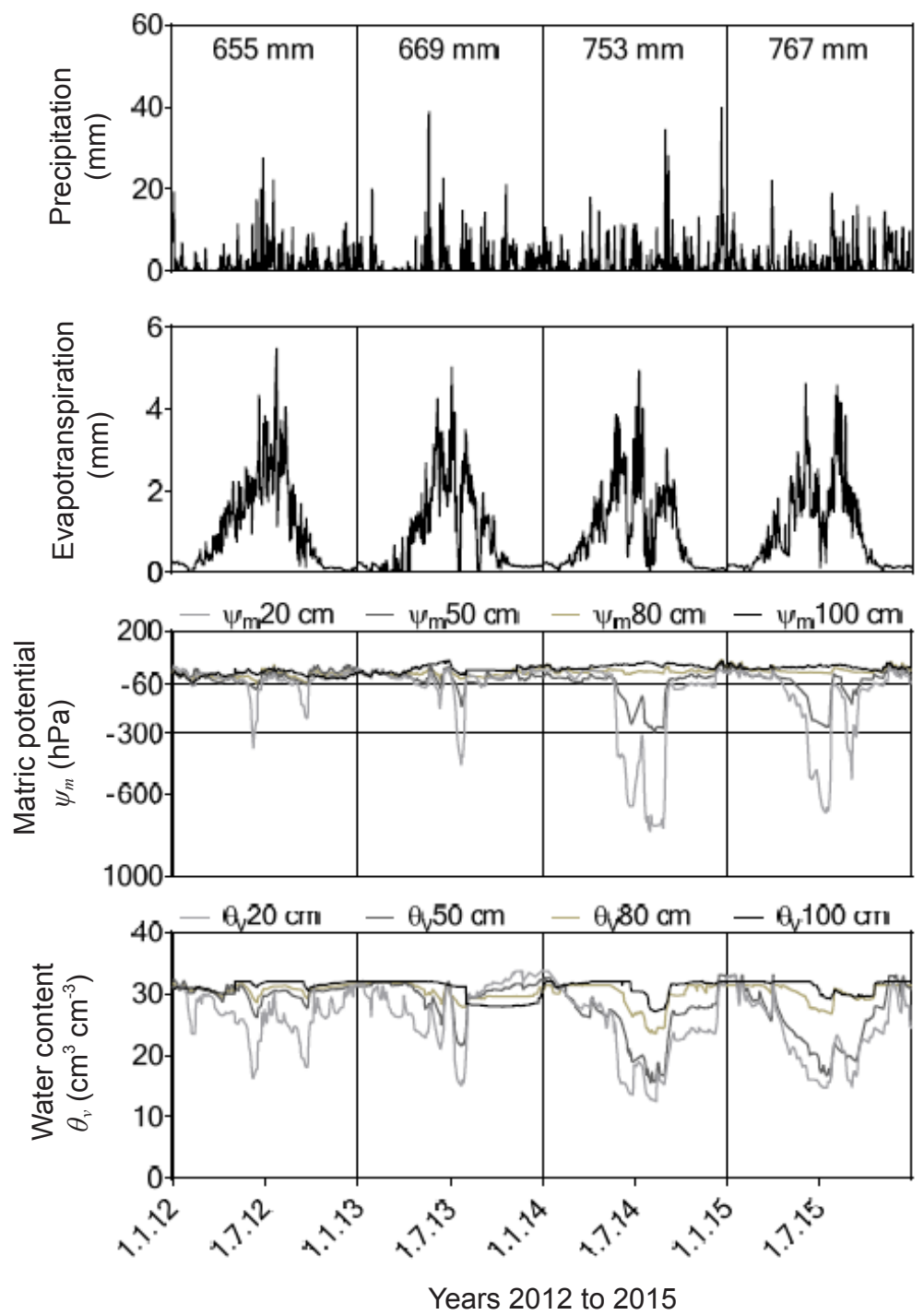

Fig. 2. Precipitation (mm), evapotranspiration (mm), matric potential $\psi_{m}(\mathrm{hPa})$ and water content $\theta_{v}\left(\mathrm{~cm}^{3} \mathrm{~cm}^{-3}\right)$ at depths of $20,50,80$ and $100 \mathrm{~cm}$ from 2012 to 2015 .

sealing layer $(>70 \mathrm{~cm})$, matric potentials $<-100 \mathrm{hPa}$ and a degree of saturation between 91 and $94 \%$ were never documented.

\section{DISCUSSION}

With the exception of the humus topsoil layer (0-5, $0-20 \mathrm{~cm}$ ), the bulk density values in the range of 1.77 to $1.88 \mathrm{~g} \mathrm{~cm}^{-3}$ were induced by mechanical stresses during the installation phase of the capping system. With the reduction of the coarser pores, the Ks values, AC and AWC are to be expected (Kutilek et al., 2006). The more stable fine pores also increased, in contrast to loosely packed soils (Horn and Smucker, 2005). Furthermore, soil compaction reduced the biotic activity (i.e. earthworms), and also the plant root growth and activity (Hoorman et al., 2009). In addition, the adsorption of humic acids to the mineral particles of the boulder marl encouraged the adhesion of soil particles. This resulted in an increasing AWC due to a higher amount of narrow coarse and medium pores (Maylavarapu and Zinati, 2009).

In the study area, hydrologic cycles of precipitation up to $45 \mathrm{~mm}^{-1 a y}{ }^{-1}$ and evapotranspiration rates up to $5.5 \mathrm{~mm}$ day $^{-1}$ induced temporary and partially reversible changes in soil properties, due to variations of matric potentials in the saturated and unsaturated zone corresponding to investigations of Oleszczuk and Brandyk (2008). The addition of compost increased both the AWC and the AC. This, with regard to the intended improvement of the capping system, was beneficial as it brought about an optimum plant growth and root water uptake of the grassland, as well as 
a high evapotranspiration (Hupe et al., 2003) and a small leachate rate (Greiffenhagen et al., 2006). Moreover, the compost addition stabilized the organic carbon pool of the soil-compost mixture and ensured sustainable conditions to the related AWC (Adani et al., 2007).

However, apart from the positive effects of the organic amendments on physical properties and functions, according to Maylavarapu and Zinati (2009), we also need to analyze the critical aspects of the compost addition. Compost consists of hydrophobic substances (e.g. humic, fulvic or long-chained fatty acids) and hydrophobic (nonpolar) functional groups. These are the main factors in the creation of a reduced soil wettability within the recultivation layer (Albacete et al., 2014; Ruggieri et al., 2008), especially during drier summer months. In particular, the adsorption of humic acids to the mineral particles of sandy soils with a low specific surface (Scheffer/Schachtschabel. 2016) generally results in higher contact angles (Wang et al., 2010) and an increasing hydrophobicity (Babejová, 2001).

Diercks (2015) analyzed the degree of hydrophobicity of the soil-compost mixture with a repellence index (RI) from the relationship of the intrinsic sorptivity of water $\left(\mathrm{S}_{\text {Water }}\right)$ and ethanol $\left(\mathrm{S}_{\text {Ethanol }}\right)$. Therefore, a $\mathrm{RI}=1$ described hydrophilic conditions, whereas a $\mathrm{RI} \geq 1.95$ displays hydrophobicity according to investigations of Hallett and Young (1999). The RI values of the soil-compost mixture ranged between 0.5 and 2.9; accordingly, the compost addition of $10.000 \mathrm{~kg}$ dry substance per cubic metre favoured a hydrophobic tendency (Diercks, 2015). Even if it did not exceed the critical value of 1.95 (Hallett and Young, 1999), such increase coincided with reduced infiltration behaviour due to a reduced local connectivity of flow pathways.

This is consistent with the findings by Lamparter et al. (2006). If we, furthermore, include the negative effects of hydrophobicity on the capillary rise (Bachmann et al., 2001), the root water uptake in the topsoil layers induces a more intense drying and, in combination, also a more intense shrinkage and aggregation. Apart from the fact that the $\mathrm{AC}$ is likely to increase, the amount of plant available water is mostly negatively affected, and may, in the long term, even bring about a failure of the total capping system due to an increased infiltration into the waste body. The extent of such processes certainly depends on the variability of the hydraulic conductivity itself, as it is influenced by the statically and temporally variable hydrophobicity, connectivity, and interaction of the pore structure (Lamparter et al., 2006; Voelkner et al., 2015). An often-discussed topic is the self-healing potential (re-swelling) of shrinkage cracks, along with the initial shrinkage pathways during the wetting process (Li et al., 2016; Peng et al., 2007). Jasinska et al. (2006) described the interaction between pre-drying and the occurrence of hydrophobic or hydrophilic behaviour within soil surfaces.
Thus, the structure formation due to shrinkage and swelling in compost-enriched soils must be discussed in view of the maximum drying intensity and frequency. Such a study has not been undertaken to date. However, Gebhardt et al. (2010) analysed Gleysols concerning the volume change and irreversibility (including hydrophobicity) and mentioned such behaviour as well. Thus, we need at least to include such processes and altered functions when dealing with organic materials, like compost, as amendment.

There are strict requirements within the German landfill directive (2009) wherein the compost addition must show a maximum electrical conductivity of $\leq 500 \mu \mathrm{S} \mathrm{cm} \mathrm{c}^{-1}$. In fact, the electrical conductivity of the soil-compost mixture in Rastorf increased up to $120 \mu \mathrm{S} \mathrm{cm}^{-1}$ after compost addition due to an increasing potassium satiation (Diercks, 2015), and hence it adheres to the statutory requirements.

As regards the requested rigidity of soil physical properties for the capping system, the soil-compost mixture must also guarantee a sufficient water storage capacity to prevent a shrinkage-induced volume loss (Horn et al., 2014), which, in combination, with a possible hydrophobicity, would end in a more permeable layer. In particular, a sealing layer low shrinkage crack potential must be ensured during drier periods so as to prevent higher leachate rates.

The safe way to prevent such processes is through determining the critical matric potential (Witt and Zeh, 2005). This defines the persistence of physical and physicochemical properties and functions. Beck-Broichsitter et al. (2016) successfully applied this concept and saw that under the given climatic and construction limitation, a matric potential in the range of -300 to $-500 \mathrm{hPa}$ serves as a limit to preventing shrinkage cracks in the sealing layer.

\section{CONCLUSIONS}

1. It is necessary to point out that low air capacities and plant available water capacities can be compensated by compost addition. Still, hydrophobic effects of the soil-compost mixture may impact the shrinkage cracking behaviour of the recultivation layer during seasonal wetting-drying cycles. Hence, laboratory and field measurements are essential to investigate the effect of the compost addition under in situ conditions.

2. The wetting inhibition, in conjunction with more negative matric potentials in the recultivation layer after compost addition, induced a critical shrinkage crack formation that should still be observed in order to exclude any impairments of the functionality of the sealing layer in the case of more intense drying processes. As a result, a significant increase of leachate would be an indication for shrinkage crack formation (macropore flow pathways) with higher Ks values and a decreasing functionality of the mineral sealing layer. 
3. Moreover, steady annual leachate rates between $10-14 \%$ of the precipitation, and the sufficiently moistened mineral sealing layer with matric potentials $<-100 \mathrm{hPa}$ during the period of investigation between 2012 and 2015, emphasise the continuous sealing effect of the temporary capping system.

Conflict of interest: The Authors do not declare conflict of interest.

\section{REFERENCES}

Adani F., Genevini, P., Ricca G., Tambone F., and Montoneri E., 2007. Modification of soil humic matter after 4 years of compost application. Waste Manag., 27, 319-324.

Albacete M.G., Tarquis A.M., and Cartagena M.C., 2014. Risk of leaching in soils amended by compost and digestate from municipal solid waste. SCI World J., doi: 10.1155/ 2014/565174

Allen G.A., Pereira L.S., Raes D., and Smith M., 1998. Crop Evapotranspiration - Guidelines for Computing Crop Water Requirements. FAO Irrigation Drainage Paper 56, Rome, Italy: 78-86.

Babejová N., 2001. An innfluence of changing the humic acids content on soil water repellency and saturated hydraulic conductivity. J. Hydrol. Hydromech., 49, 91-300.

Bachmann J., Horton R., and van der Ploeg R.R., 2001. Isothermal and nonisothermal evaporation from four sandy soils of different water repellency. Soil Sci. Soc. Amer. J., 65(6): 1599-1607.

Bayer J.V. and Schaumann G.E., 2007. Development of soil water repellency in the course of isothermal drying and upon pH 15 changes in two urban soils, Hydrol. Process., 21, 2266-2275.

Blakemore L.C., Searle P.L., and Daly B.K., 1987. Methods for chemical analysis of soils. New Zealand Soil Bureau Science Report 80.

Beck-Broichsitter S., Fleige H., and Horn R., 2016. Schrumpfrissgefährdung einer temporären mineralischen Oberflächenabdeckung. Deponietechnik, Januar 27-28, Hamburg, Germany.

Beck Broichsitter S., Fleige H., and Horn R., 2017. Waste capping systems processes and consequences for the longterm impermeability. In: Soils within Cities (Eds M. Levin, H.J. Kim, J.L. Morel, W. Burghardt, P. Charzynski, R.K. Shaw). Catena Soil Sciences, Stuttgart, Germany.

Blake G.R. and Hartge K.H., 1986. Bulk density, in: Klute, A. (eds.): Methods of Soil Analysis, Part 1., 2nd ed. ASA and SSSA, Madison, WI, USA, pp. 363-375.

Diercks C., 2015. Wirkung von Gärrest und Fertigkompost auf chemische und biologische Parameter unterschiedlich textuierter Böden im Vergleich. Masterarbeit. Institut für Pflanzenernährung und Bodenkunde der ChristianAlbrechts-Universität zu Kiel.

FAO, 2006. Guidelines for Soil Description. FAO-ISRIC Press, Rome, Italy.

Gebhardt S., Fleige H., and Horn R., 2010. Shrinkage processes of a drained riparian peatland with subsidence morphology J. Soils Sed., 10, 484-493.
Gebhardt S., Fleige H., and Horn R., 2010. Shrinkage processes of a drained riparian peatland with subsidence morphology J. Soils Sed., 10: 484-493.

Germann landfill directive, 2009. Degree on landfills (ordinance to simplify the landfill law) - Germany, in the form of the resolution of the Federal Cabinet dated April 27th 2009.

Greiffenhagen A., Wessolek G., Facklam M., Renger M., and Stoffregen H., 2006. Hydraulic functions and water repellency of forest floor horizons on sandy soils. Geoderma, 132: 182-195.

Hallett P.D. and Young I.M., 1999. Changes to water repellency of soil aggregates caused by substrate-induced microbial activity. Eur. J. Soil Sci., 50, 35-40.

Hartge K.H., 1966. Ein Haubenpermeameter zum schnellen Durchmessen zahlreicher Stechzylinderproben. Zeitschrift für Kulturtechnik und Flurbereinigung, 7, 155-163.

Hoorman J.J., 2009. Using cover crops to improve soil and water quality. Agriculture and Natural Resources. The Ohio State University Extension Press, Lima, Ohio, 1-4.

Horn R. and Smucker A., 2005. Structure formation and its consequences for gas and water transport in unsaturated arable and forest soils. Soil Till. Res., 82: 5-14.

Horn R., Peng X., Fleige H., and Dörner J., 2014. Pore rigidy in structured soils - only a theoretical boundary condition for hydraulic properties. J. Soil Sci. Plant Nutr., 60: 3-14.

Hoornweg D. and Bhada-Tata P., 2012. What a Waste: A Global Review of Solid Waste Management. Urban Development Series, Knowledge Papers, The World Bank, Washington, DC, USA.

Hupe K., Heyer K.-U., Becker J.F., Traore O., Noetzel S., and Stegmann R., 2003. Investigations of alternative landfill surface sealing systems in test fields. 9th Int. Waste Management and Landfill Symposium, October 6-10, Sardinia, Italy.

Jasinska E., Wetzel H., Baumgartl T., and Horn R., 2006. Heterogeneity of physico-chemical properties in structured soils and its consequences. Pedosphere, 16, 284-296

Kutilek M., Jenele L., and Panayiotopoulos K.P., 2006. The influence of unaxial compression upon pore size distribution in bi-modal soils. Soil Till. Res., 79, 175-184.

Lamparter A., Deurer M., Bachmann J., and Duijnisveld W.H.M., 2006. Effect of subcritical hydrophobicity in a sandy soil on water infiltration and mobile water content. J. Plant Nutr. Soil Sci., 169, 38-46.

Laner D., Crest M., Scharff H., Morris J.W., and Barlaz M.A., 2012. A review of approaches for the long-term management of municipal solid waste landfills. Waste Manag., 32, 498-512.

Li J.H., Li L., Chen R., and Li D.Q., 2016. Cracking and vertical preferential flow through landfill clay liners. Eng. Geol., 206, 33-41.

Maylavarapu R.S. and Zinati G.M., 2009. Improvement of soil properties using compost for optimum parsley production in sandy soils. Scienta Horticulturae, 120, 426-430.

Oleszczuk R. and Brandyk T., 2008. The analysis of shrinkageswelling behaviour of peat-moorsh soil aggregates during drying-wetting cycles. Agronomy Res., 6(1), 131-140.

Peng X., Horn R., and Smucker A., 2007. Pore Shrinkage dependency of inorganic and organic soils on wetting and drying cycles. Soil Sci. Soc. Am. J., 71, 1095-1104. 
Rowe R.K., 2011. Systems engineering: the design and operation of municipal solid waste landfills to minimize contamination of groundwater. Geosynth. Int., 18(6), 391-404.

Ruggieri L., Artola A., Gea T., and Sanchez A., 2008. Biodegradation of animal fats in a co-composting process with wastewater sludge. Int. Biodeter Biodegr., 62(3), 297-303.

Saito T., Fujimaki H., Yasuda H., Inosako K., and Inoue M., 2013. Calibration of temperature effect on dielectric probes using time series field data. Vadose Zone J., 12(2), 184-189.

Scheffer/Schachtschabel., 2016. Soil Science (Eds H.-P. Blume, G.W. Brümmer, R. Horn, E. Kandeler, I. Kögel-Knabner, R. Kretzschmar, P. Schad, K. Stahr, B.-M. Wilke). Springer Verlag Berlin Heidelberg.

Stępniewski W., Widomski M.K., and Horn R., 2011. Hydraulic conductivity and landfill construction. In: Developments in hydraulic conductivity research (Ed. O. Dikinya). Intech, Rijeka, Croatia.
Voelkner A., Ohl S., Holthusen D., Hartung E., Dörner J., and Horn R., 2015. Impact of mechanically pre-treated anorganic digestates on soil properties. J. Soil Sci. Plant Nutr., 15(4), 882-895.

Wang X.Y., Zhao Y., and Horn R., 2010. Soil wettability as affected by soil characteristics and land use. Pedosphere, 20, 43-54.

Widomski M.K., Beck-Broichsitter S., Zink A., Fleige H., and Horn R., 2015. Numerical modelling of water balance for temporary landfill cover in North Germany. J. Plant Nutr. Soil Sci., 178(3), 401-412.

Witt K.J. and Zeh R.M., 2005. Crack due desiccation in cover lining systems. Phenomena and design strategy. Int. Workshop 'Hydro-Physico-Mechanics of Landfills', March 21-22, Grenoble, France. 